\title{
Adolescent Moslem Students Sleep Hygiene Behaviour Description At Pondok Pesantren
}

\author{
Siti Nur Alfiyah,F. Sri, Kurniawan Yudianto \\ Faculty of Nursing, Universitas Padjadjaran \\ Email : sitinuralfyah04@gmail.com
}

\begin{abstract}
School activities and socialization consume a lot of time for adolescents and leave a little time for adolescents to rest or sleep. Changes in environment, independence and changes in sleep patterns commonly occur for students who undergo pesantren activities, thus affecting the quantity and sleep quality of students. Sleep deprivation is associated with poor sleep hygiene behaviour. This study used descriptive quantitative method with single variable. Sampling technique used at this study is stratified random sampling. This study involved as many as 161 adolescent moslem students at the age of 11-20 years in Pondok Pesantren Darul Hikmah Tanjungmekar Tanjungkerta Sumedang Distric. Data collected by using Adolescent Sleep Hygiene Scale Questionnaire and analyzed by using mean value. The result of this study showed that more than half of the respondents had good sleep hygiene practices $(68,3 \%)$. There are four aspects of adolescent moslem students sleep hygiene in good category : cognitive/emotional aspect, sleep environment aspect, sleep stability aspect and substance use aspect. Two aspects of sleep hygiene in bad category are in the daytime sleep aspect and bedtime routine aspects. Meanwhile physiological aspect and behavioural arousal aspect have an almost balance values. Monitoring moslem students sleep schedule not to exceed 24.00, providing separate room for moslem study self study, habits of toothbrush before bed, monitoring of cigarette use in cottage environment, not providing tea at dinner time, and monitoring of moslem students activity outside school or cottage Pesantren is a thing that should be attention.
\end{abstract}

Keywords: Adolescent, moslem students, sleep hygiene.

\section{Gambaran Sleep Hygiene Santri Remaja Pondok Pesantren}

\begin{abstract}
Abstrak
Aktivitas sekolah dan sosialisasi yang dilakukan oleh remaja mengakibatkan banyaknya waktu yang tersita dan hanya sedikit waktu yang disisakan untuk beristirahat ataupun tidur. Perubahan lingkungan, kemandirian dan perubahan pola tidur yang tajam biasa terjadi bagi siswa yang menjalani kegiatan pesantren, sehingga berpengaruh terhadap kuantitas dan kualitas tidur siswa. Kekurangan tidur ini berhubungan dengan buruknya perilaku sleep hygiene. Penelitian ini bertujuan untuk mengetahui gambaran 8 aspek sleep hygiene, serta gambaran sleep hygiene berdasarkan latar belakang demografi santri. Penelitian ini menggunakan desain deskriptif kuantitatif dengan variabel tunggal. Adapun teknik sampling yang digunakan yaitu stratified random sampling. Penelitian dilakukan terhadap 161 santri remaja usia 11-20 tahun di Pondok Pesantren Darul Hikmah Tanjungmekar Kecamatan Tanjungkerta Kabupaten Sumedang. Data dikumpulkan menggunakan kuesioner Adolescent Sleep Hygiene Scale serta dianalisis menggunakan nilai mean. Hasil penelitian ini menunjukkan bahwa sebanyak 68,3\% responden memiliki praktik sleep hygiene yang baik. Aspek-aspek sleep hygiene santri yang berada dalam kategori baik terdapat pada aspek kognitif emosional, aspek lingkungan tidur, aspek stabilitas tidur dan aspek penggunaan substansi. Adapun 2 aspek sleep hygiene yang berada dalam kategori buruk terdapat pada aspek tidur siang dan aspek rutinitas sebelum tidur. Sedangkan aspek fisiologis dan aspek perilaku penggugah memiliki hasil yang hampir seimbang. Memantau jadwal tidur santri agar tidak melebihi pukul 24.00, menyediakan ruangan terpisah bagi santri untuk belajar mandiri, pembiasaan sikat gigi sebelum tidur, pemantauan penggunaan rokok di lingkungan pondok, tidak menyediakan teh pada saat jam makan malam, dan pemantauan kegiatan santri diluar jam sekolah ataupun pondok pesantren merupakan hal yang sebaiknya pengurus pondok pesantren perhatikan.
\end{abstract}

Kata kunci : Remaja, santri, sleep hygiene. 
Siti Nur Alfiyah : Adolescent Moslem Students Sleep Hygiene Behaviour Description

\section{Introduction}

School activities and socializing are the parts of the adolescent development tasks that must be undertaken. The amount of time spent on the activity let a little time left for teenagers to rest or sleep. Based on data from the National Sleep Foundation (2006) 56\% of high school adolescents $(n=1602)$ had lost sleep time than the requirement. Besides the quantity of sleep that was lacking, $39 \%$ of high school teenagers were reported experiencing Excessive Daytime Sleepiness for several days a week. In Indonesia, the prevalence of sleep disturbances increased by $62.9 \%$ among adolescents aged 12-15 years in East Jakarta, wake-to-sleep transition disorders were the most common type of disorder. A total of $72.9 \%$ of them had different sleep schedule patterns between school days and weekends (Haryono et al., 2009).

In addition to inadequate sleep time, sleep disturbance can affect the sleep quality of teenagers. This refers to the research conducted by Maryani (2009) that $84.09 \%$ (n $=88$ ) students in Madrasah Aliyah Negeri 2 Bandung had poor sleep quality. In another study of adolescent students who underwent an accelerated education program at 5 Junior High School Bandung, 77\% $(\mathrm{n}=39)$ students had poor sleep quality. Poor sleep quality in these students related to the teaching materials which completed in a relatively short time, i.e. 4 months (Amandaty, 2014). According to Malone (2011), inadequate sleep in adolescents will affect cognitive function, memory, safety, mental health, and the occurrence of weight loss.

Based on the above explanations, cognitive function and remembering process are important for teenagers. It has a contribution to the learning process, especially for adolescents who undergo educational system in boarding schools. Additional activities such as memorizing Al-Quran, hadith or a holy book is a characteristic of boarding education model outside of formal education activities. Apart from having a different education system, boarding schools require all the students to settle and run various activities in a dormitory.

Most of the boarding schools in Indonesia assign the rules for the students to stay in the dorm and arrange sleeping and waking hours. Environmental changes, independence and extreme changes in sleep patterns are common for those who are freshmen in the boarding school (Saifudin, 2012). In obtaining good sleep quality, adequate sleep duration, and full day-time alertness required a behaviour and environmental modification called sleep hygiene.

Sleep hygiene is divided into 8 aspects include physiological (e.g. caffeine consumption at night), arousal behavior (e.g. using a bed for activity other than sleeping), cognitive/emotional (e.g. sleeping in unstable psychological conditions), the sleeping environment (e.g. can fall asleep in the light turned on), sleep stability (e.g. daily and weekly sleep-to-wake different schedule), the substance usage (e.g. alcohol use at night) the napping (e.g. taking a nap), and routine activity before bedtime (e.g. hot bath) (LeBourgeois et al, 2005).

Related to the importance of sleep hygiene for students, the researchers were interested to explore the depiction of sleep hygiene in students of Pondok Pesantren Darul Hikmah (boarding school) at Tanjungmekar Tanjungkerta Sumedang District. This research was expected to be useful in designing a health promotion about sleep hygiene for a special group of students in fulfilling their rest requirement.

\section{Research Method}

The study used a quantitative descriptive method with a single variable. The population in this study included students of Pondok Pesantren (boarding school) Darul Hikmah Tanjungmekar Tanjungkerta Sumedang District with a total of 269 students. The sampling technique used stratified random sampling and Slovin formula to determine the number of samples with the error rate of $5 \%$, whilst to determine the number of stratified sample members was done by the proportional allocation formula. Samples were taken randomly based on the education level of the students, the number of respondents in this study was 161 people.

This research used the inventory Adolescent Sleep Hygiene Scale (ASHS) 
Siti Nur Alfiyah : Adolescent Moslem Students Sleep Hygiene Behaviour Description

questionnaire from LeBourgeois et al., (2005). ASHS had 33 personal report items in measuring and assessing sleep hygiene which was divided into 6 items of qualitative statements to determine the sleep-wake schedule habits on weekdays and holidays, and 27 items of quantitative statements used in calculating the score of 8 aspects of sleep hygiene. However, this study only used 26 quantitative items that have been adapted to the condition of boarding school. The one item questionnaire that was not taken by researchers relating to short sleep at $6 \mathrm{pm}$. Researchers have conducted a Cronbach alpha test of 30 students of Pondok Pesantren (boarding school) Assaadah Babakan Ciwaringin Cirebon District and obtained Cronbach alpha value of 0.700 .

Assessment on this ASHS questionnaire using Likert scale with $6=$ never, $5=$ very frequent but not routine, $4=$ quite often, 3 $=$ sometimes, $2=$ seldom and $1=$ always $/$ routine. In this questionnaire there was one aspect of using reverse-scoring that was on the aspect of routine activity before bed, thus the assessment on this aspect score $1=$ never, $2=$ very frequent but not routine, $3=$ quite often, $4=$ sometimes, $5=$ seldom and $6=$ always/routine.

Adolescent Sleep Hygiene Scale has a data analysis technique using the mean score of 8 aspects of sleep hygiene that measured. Scores of each sleep hygiene aspect were obtained from the mean of each item, and the mean score of each aspect was used to determine the overall total sleep hygiene score (LeBourgeois et al., 2005). The sleep hygiene measurement results were divided into 2 categories: good and poor. Furthermore, to determine the distribution of students' sleep hygiene category used a frequency distribution.

Table 1 Sleep Hygiene Based on the Characteristics of Respondents $(n=161)$

\begin{tabular}{|c|c|c|c|c|c|}
\hline \multicolumn{2}{|c|}{ Characteristics of Respondents } & \multicolumn{4}{|c|}{ Sleep Hygiene } \\
\hline & & \multicolumn{2}{|c|}{ Good } & \multicolumn{2}{|c|}{ Poor } \\
\hline & & f & $\%$ & f & $\%$ \\
\hline \multirow[t]{2}{*}{ Gende } & Male & 59 & 81.9 & 13 & 18.1 \\
\hline & Female & 51 & 57.3 & 38 & 42.7 \\
\hline \multirow[t]{3}{*}{ Age } & $11-14$ years old & 61 & 79.2 & 16 & 20.8 \\
\hline & 15-17 years old & 44 & 57.9 & 32 & 42.1 \\
\hline & $18-20$ years old & 5 & 62.5 & 3 & 37.5 \\
\hline \multirow{3}{*}{$\begin{array}{l}\text { Adolescents' } \\
\text { Development } \\
\text { Stage }\end{array}$} & Early & 61 & 79.2 & 16 & 20.8 \\
\hline & Middle & 44 & 57.9 & 32 & 42.1 \\
\hline & Late & 5 & 62.5 & 3 & 37.5 \\
\hline \multirow{2}{*}{$\begin{array}{l}\text { Educational } \\
\text { Level }\end{array}$} & JHS & 83 & 73.5 & 30 & 26.5 \\
\hline & SHS & 27 & 56.3 & 21 & 43.8 \\
\hline \multirow{5}{*}{$\begin{array}{l}\text { Extracurricular } \\
\text { followed }\end{array}$} & 1 & 70 & 65.4 & 37 & 34.6 \\
\hline & 2 & 16 & 88.9 & 2 & 11.1 \\
\hline & 3 & 2 & 50 & 2 & 50 \\
\hline & $>3$ & 4 & 100 & 0 & 0 \\
\hline & None & 18 & 64.3 & 10 & 35.7 \\
\hline
\end{tabular}


Siti Nur Alfiyah : Adolescent Moslem Students Sleep Hygiene Behaviour Description

Table 2 Description of Sleep Hygiene of Students at Pondok Pesantren Darul Hikmah ( $\mathrm{n}=161)$

\begin{tabular}{lccccc}
\hline \multirow{1}{*}{ Research Variables } & Mean & \multicolumn{3}{c}{ Category } \\
\cline { 3 - 6 } & & G & \% & f & Poor \\
\cline { 3 - 6 } & & 110 & 68.3 & 51 & 31.7 \\
\hline Overall Sleep Hygiene & 4.41 & & & & \\
Based on: & & 81 & 50.3 & 80 & 49.7 \\
Physiological aspect & 5.03 & 81 & 50.3 & 80 & 49.7 \\
Arousal behaviour aspect & 3.72 & 84 & 52.2 & 77 & 47.8 \\
Cognitive/emotional aspect & 4.62 & 89 & 55.3 & 72 & 44.7 \\
Sleeping environment & 4.72 & & & & \\
aspect & & 93 & 57.8 & 68 & 42.2 \\
Sleep stability aspect & 4.32 & 75 & 46.6 & 86 & 53.4 \\
The napping aspect & 4.28 & 152 & 94.4 & 9 & 5.6 \\
The substance usage aspect & 5.95 & 77 & 47.8 & 84 & 52.2 \\
Routine activity before & 2.59 & & & & \\
bedtime aspect & & & & & \\
\hline
\end{tabular}

\section{Research Results}

Data collection of sleep hygiene on the students was conducted on 19-20 May 2017 to 161 respondents. The research was taken in Pondok Pesantren (boarding school) Darul Hikmah Tanjungmekar Tanjungkerta Sumedang District. Out of the 161 respondents, more than half of them $(55.3 \%)$ were female, nearly half of them $(47.8 \%)$ were in the 11-14 age range or were in early adolescence stage, the most of them $(70,2 \%)$ were in junior high school, and most respondents $(66.5 \%)$ participated in 1 extracurricular. The following table shows the sleep hygiene based on demographic data of students.

Based on demographic background, more than half of male respondents had good sleep hygiene $(81.9 \%)$ than female $(57.3 \%)$. As for respondents aged 15-17 years who in the middle adolescent development stage had the worst sleep hygiene practice $(42.1 \%)$. In addition, more than half of the respondents with junior high school education had good sleep hygiene practice $(73.5 \%)$, whereas those with high school education level were $56.3 \%$. Based on the number of extracurricular that followed, students who followed more than 3 extracurricular had the best sleep hygiene practice $(100 \%)$.
Table 2 below presents the sleep hygiene overview of students of Pondok Pesatren Darul Hikmah.

Based on table 2, sleep hygiene of the students had a mean of 4.41. The largest mean score was in the substance usage aspect of 5.95, and the lowest mean score was in the aspect of routine activity before bedtime of 2.59. From the research results can be perceived that 6 of the 8 aspects of sleep hygiene were in good category, with physiological aspects $50.3 \%$, the arousal behavior aspect $50.3 \%$, cognitive/emotional aspect $52.2 \%$, sleeping environment aspect $55.3 \%$ aspects of sleep stability aspect $57.8 \%$ and the substance usage aspect $94.4 \%$. The napping and routine activities before bedtime aspects had the worst category of $53.4 \%$ and $52.2 \%$.

\section{Discussion}

Description of Sleep Hygiene Aspects

Based on the results of the study, the sleep hygiene of students of Darul Hikmah on the physiological aspect was in a good category $(50,3 \%)$. One of the students' good activities on the physiological aspect that they did not sleep in hunger since Darul Hikmah boarding school provided and arranged dinner for them. 
Siti Nur Alfiyah : Adolescent Moslem Students Sleep Hygiene Behaviour Description

Besides providing dinner, the boarding school had a cafeteria that still provided snacks at night. According to Potter \& Perry (2005) going to bed with an empty stomach can cause a person to wake up and awake at night so that will interfere sleeping time. Another activity on the physiological aspect that they did not do a heavy physical activity one hour before bedtime. That was in contrast to sleep hygiene study by Nursalam, et al (2013) on 46 adolescent students in Bali, they often did keen activities one hour before bedtime, i.e. running. In general, adolescent students in Bali had less sleep hygiene practices, but for the physiological aspects, they performed adequately.

Based on immediate observations during data collection, boarding school always had a variety of regulations that drove the conducive activities inside the dormitory. The curfew and regular activities after sunset prayer and isya induced the students to do light activities such as reciting Al-Quran. This had a good effect because students did not get the opportunity to perform heavy physical activities before bedtime.

Arousal behaviour activities in the assessment of students' sleep hygiene practices included the things caused the students feel very awake (reading, memorizing, doing homework, chatting) in bed. The absence of electronic devices such as television and mobile phone for students as the mean of communication, entertainment or reading sources has a role in promoting a good sleep hygiene practice (50.3\%). Research by Chang, Aesbach, \& Duffy (2014) reading using electronic devices one hour before bedtime can reduce sleep subjectivity, reduce delta/theta EEG activity, and suppress melatonin expenditure in the pineal gland rather than people reading with a printed book.

Based on the research results, students used their rooms to perform various activities other than to sleep. This was more underwent by female than male students. Women were more likely to do homework or chat in bed.

In the cognitive/emotional aspect, 52.2\% students of Darul Hikmah boarding school had a good sleep hygiene practice. This study was consistent with the study of sleep hygiene by Galland et al. (2017) to 692 New Zealand adolescents, they had a better cognitive/ emotional aspect in male compared to the female adolescents. Pesantren (boarding school) education model was usually more emphasis on character building education which was formed by habituation in the dormitory through clear rules. The goodness of cognitive/emotional aspect of students' sleep hygiene behaviour as a result students aware of attitude to solve the problem. This occurred by means of the strong character that has formed by positive habits within the boarding school, so students did not bring any unstable psychological condition into their sleep hygiene practice.

Related to the sleep environment aspect, there were some things that must be considered, including the safe and comfortable conditions of the room. In this study found that 55,3\% students had a good sleep environment aspect. Although at the earlier data collection found some students moved during night-time sleep due to feeling noisy or uncomfortable with the room temperature, but it did not provide significant value to sleep hygiene practice in the sleep environment aspect.

One of the activities included in the assessment of the sleep environment aspect was not listening to loud and high volume music, this activity provided the most significant value to students' sleep hygiene practice. The unavailability of mobile phones or other electronic devices as entertainment media for students gave a good role for their sleep hygiene practice, so they did not have the opportunity to listen to high-volume music just before bedtime.

This condition was different from adolescents living with the family at home or those who did not live boarding life. Based on the findings by Nursalam, et al (2013) that adolescents in Bali evenly often listened to music with a loud volume just before bedtime. They assumed that loud music can help them to sleep, but there was no research on the effectiveness of loud music on the quantity and quality of sleep.

According to the research results, students of Darul Hikmah had a very less score for not sleeping in a room with lights on. The regulation of turning on the lamp while the students were sleeping did not fit the healthy 
Siti Nur Alfiyah : Adolescent Moslem Students Sleep Hygiene Behaviour Description

sleep suggestion. In addition to slowing the expenditure of melatonin, room lights that remain lit during sleep will make the students had poor sleep hygiene practices on arousal behaviour and sleep stability aspects. This can provide an opportunity for the students to delay sleep time by interacting or other activities in bed.

Setting a bedtime on school day and weekends was an attempt to address the sleep stability aspect of sleep hygiene. In general, Darul Hikmah boarding school provided breaks from 22.00 to 03.00. Based on the results, 57.8\% students of Darul Hikmah boarding school had good sleep hygiene category in sleep stability aspect.

Good sleep stability in students of Darul Hikmah boarding school cannot be separated from the role of dormitory management as a substitute for the family at home, the role of Lurah Pondok as the closest board for the students supported the obedience students in arranging bedtime. However, monitoring of bedtime during the weekend should be paid more attention, considering there were still some students who slept after 24.00.

Revealed in the research results, more than half of the students (53.4\%) of Darul Hikmah boarding school had a bad nap aspect. According to LeBourgeois et al., (2005) napping activity will increase along with the adolescents' development. A long nap on an individual may indicate poor quality of sleep as well as increased night-time alertness (Tsai \& Li, 2004). The students' less quantity or quality of sleep at night was paid the next day by a long nap. The use of free time after school hours by following various additional activities can reduce the nap, in addition to suppressing the day-time sleep activities, this can affect students to sleep on time stick to the night-time rules of the dormitory. Students who had been napping tended to be more difficult to sleep at night.

In this study also obtained the result that almost all students (94.4\%) of Darul Hikmah boarding school had a good substance usage aspect, there were no students of Darul Hikmah boarding school who drank alcohol. But there were some students who smoked after 6 o'clock, even they did it every day. This aspect had the greatest percentage of students' sleep hygiene practice. The male students smoked cigarettes as a way to express their anxiety or stress. Therefore, more attention is needed from boarding dormitory related to it by holding activity of stress management for students regularly.

In the routine activity before bedtime aspect, more than half of the students $(52.2 \%)$ of Darul Hikmah had a bad percentage. It was similar to the study conducted by Galland et al (2017) against adolescents aged 15-17 in New Zealand who had poor sleep hygiene in the routine activity before bedtime aspect but only in the male. Activities such as hot bathing or soaking feet with warm water, and doing massage or aromatherapy can be replaced with the Al-Quran recitation before bed, as the boarding school did not provide facilities for the use of warm water or aromatherapy for students. The needs to habituate regular activities before bedtime such as brushing your teeth, reciting the Al-Quran and praying together can improve the sense of comfort for the students before going to bed.

Description of Students' Sleep Hygiene Based on Demographic Background

In general, the respondents in this study were dominated by female students in early adolescence, where they were studying the first-grade school and following 1 extracurricular. The study results indicated that male had a good sleep hygiene practice compared to the female students. The arousal behaviour and cognitive/emotional aspects were the worst aspects of sleeping hygiene practice in the female. This was corresponding to the research conducted by Galland et al (2017), such activities as checking the clock frequently at night, doing homework in the bed, and thinking over something unnoticed were the things led to poor sleep quality.

Mainly, students were required to stay in a dorm so that all activities were more often done in their rooms, especially in doing homework. The existence of a certain room for self-study activities or doing homework is a thing that should be recognized by the management so that students do not do any other activities in their rooms.

In this study, students of Darul Hikmah Islamic boarding school should pay more attention to activities that can prevent them from going to bed, i.e. by not using the bed to perform various activities other than to sleep, 
Siti Nur Alfiyah : Adolescent Moslem Students Sleep Hygiene Behaviour Description

avoiding unstable psychological conditions and the consumption of tea or coffee at night. While habituating of brushing teeth before bed and avoiding the use of cigarettes are other things that male students should pay attention.

The students of Darul Hikmah had a poor sleep hygiene practice in the 18-20 age range or at the stage of late adolescent development who was studying at high school. According to Nursalam, et al (2013) the role of peers was a very strong factor in the implementation of sleep hygiene practices in adolescents. At the stage of adolescent development, school activities and socializing are time-consuming and can affect other activities, one of them is sleeping.

The poor sleep hygiene practice in the late adolescent students who are studying at the high school can occur due to the demands of various activities, whether inside the dorm or activities in formal school. In addition to the occupied activity, academic demands in the dorm or formal school and the absence of a family role in regulating bedtime are other factors that may influence their sleep hygiene practices. This was evidenced by the research results that nearly $10 \%$ of students set up their sleep schedules after 24.00 during school days or weekends. In this case, the monitoring of the students' sleeping schedule is a matter that must be considered by the board of the dorm.

The different use of leisure times can affect students' sleep hygiene practices. This was proven by students of Darul Hikmah who had many activities by following more than 3 extracurricular got the best sleep hygiene practice. Although the boarding school provided sleep time for 5 hours, if the students obtained a good sleep hygiene and sleep quality, it will have an impact on their productivity in undergoing various activities at school or dorm.

According to Nursalam, et al (2013) lifestyle and activity patterns outside school hours was an effect on sleep hygiene practices, especially on the sleep stability aspect. The factors that influence the students' sleep hygiene practice need to be explored in further research, especially related factors that affect out of the school hours and boarding school.

\section{Conclusion}

In general, more than half of the students $(68.3 \%)$ had good sleep hygiene practices, and less than half of the respondents $(31.7 \%)$ had poor sleep hygiene practices. The students had good categories in the cognitive/emotional, the sleep environment, sleep stability and substance usage aspects. The two aspects of sleep hygiene in the bad category were in the napping and the routine activity before bedtime aspects. While the physiological and arousal behaviour aspects had almost balanced results.

Referring to the results of the study, there are several things that should be considered by the board members in supporting or maintaining good sleep hygiene practices, by monitoring the students' sleep schedule not to exceed at 24.00 , providing a separate room for students to learn independently, it can be done by giving permission to students to use classroom/other rooms at night. The next thing to note is related to the habit of brushing teeth before bed, monitoring the use of cigarettes in the dorm, not providing tea at dinner, and monitoring the activities of students outside school hours or boarding school.

For the nearest healthcare provider, especially puskesmas (community health centre), can cooperate with santri husada (students) in establishing the Sleep Smart Program through the habituation of sleep hygiene practice. Provision of health care as preventive and promotive actions for students through the continuous information given to improve the students' optimal degree of health.

\section{References}

Amandaty, S.P. (2014). Gambaran kualitas tidur siswa di SMP Negeri 5 Bandung yang mengikuti program akselerasi. Skripsi. Fakultas Keperawatan, Universitas Padjadjaran (Unpublished), Bandung.

Chang, A.M., Aeschbach, D., Duffy, J.F., \& Czeisler, C.A. (2014). Evening use of lightemitting eReaders negatively affects sleep, circadian timing, and next-morning alertness. 
Siti Nur Alfiyah : Adolescent Moslem Students Sleep Hygiene Behaviour Description

Proceedings of the National Academy of Sciences, 112(4), 201418490. https://doi. org/10.1073/pnas.1418490112.

Galland, B.C., Gray, A.R., Penno, J., Smith, C., Lobb, C., \& Taylor, R.W. (2017). Gender differences in sleep hygiene practices and sleep quality in New Zealand adolescents aged 15 to 17 years. Sleep Health. https://doi.org/ http://dx.doi.org/10.1016/j.sleh.2017.02.001.

Haryono, A., Rindiarti, A., Arianti, A., Pawitri, A., Ushuluddin, A., S.A. (2009). Prevalensi gangguan tidur pada remaja 1215 tahun di sekolah lanjutan tingkat pertama. Sari Pediatri, 11(3), 149-54. https:// saripediatri.org/index.php/sari-pediatri/ article/download/585/520.

LeBourgeois, M.K., Giannotti, F., Cortesi, F., Wolfson, A.R., Harsh, J. (2005). The relationship between reported sleep quality and sleep hygiene in Italian and American adolescents. 115(10), 257-265. https://doi. org/10.1542/peds.2004-0815H.

Malone, S.K. 2011. Early to bed, early to rise?: An exploration of adolescent sleep hygiene practices. The Journal of School Nursing. https://doi.org/10.1177/1059840511410434.

Maryani, Y. (2009). Gambaran kuantitas dan kualitas tidur siswa di MAN 2 Kota Bandung. Skripsi. Fakultas Keperawatan, Universitas Padjadjaran (Unpublished), Bandung.

National Sleep Foundation. (2006). Summary of findings. Diakses pada tanggal January 23, 2017. https://sleepfoundation.org/sites/ default/files/2006_summary_of_findings. pdf.

Nursalam, M., Apriani, N.K., Has, E.M.M., \& Efendi, F. (2013). Sleep hygiene behavior among Balinese adolescent. Journal of Nursing Education and Practice, 4(3), 155160. https://doi.org/10.5430/jnep.v4n3p155.

Potter, P.A. (2005). Buku ajar fundamental keperawatan konsep, proses dan praktik (4th ed.). Jakarta: EGC.

Saifudin, U. (2012). Hubungan antara stres dengan pola tidur pada siswa SMP pondok pesantren modern MBS di Bokoharjo, Prambanan, Sleman. Sekolah Tinggi Ilmu Kesehatan 'Aisyiyah. http://opac. unisayogya.ac.id/921/.

Tsai, L.L., \& Li, S.P. (2004). Sleep patterns in college students. Journal of Psychosomatic Research, 56(2), 231-237. https://doi. org/10.1016/S0022-3999(03)00507-5. 